\title{
STUDY ON MORPHOLOGICAL CHARACTERISTIC OF STINGLESS BEE (Heterotrigona itama) IN TERENGGANU
}

\author{
SITI NURAISHAH SAIFULLIZAN, WAHIZATUL AFZAN AZMI AND WAN BAYANI WAN \\ OMAR*
}

Faculty of Science and Marine Environment, Universiti Malaysia Terengganu, 21030 Kuala Nerus, Terengganu, Malaysia.

*Corresponding author: bayani@umt.edu.my

http://doi.org/10.46754/umtjur.2021.10.013

\begin{abstract}
Stingless bee, Heterotrigona itama is one of the most important and effective insect pollinators of many plant species. They can be found in the tropical rain forest where they build their nest in the living trees. This study was conducted to measure the morphological characteristic of H. itama from two different populations which were TKPM (Taman Kekal Pengeluaran Makanan) Kampung Peradong, Manir (A) and Big Bee Honey, Merchang (B), Terengganu. 20 individuals of $H$. itama adults were taken from each population by using insect net. The external morphologies such as body length, head, abdomen, thorax, leg, tibia, forewing, hindwing and antenna were measured by using DinoLite 2.0. The measurements were recorded and the mean \pm standard deviation and range of the measurement data were analysed. Based on Mann-Whitney test, there were significant differences for population $\mathrm{B}$ of $H$. itama in mean of head length $(\mathrm{p}=0.0016 ; \mathrm{p}<0.05)$, head width $(\mathrm{p}=0.0022 ; \mathrm{p}<0.05)$ and thorax width $(\mathrm{p}=0.0445 ; \mathrm{p}<0.05)$. However, there was no difference in body colour for $H$. itama of both populations. H. itama of population B has a larger segmented body with the range of head length at $1.179 \mathrm{~mm}$ to $2.152 \mathrm{~mm}$, head width $1.743 \mathrm{~mm}$ to $2.557 \mathrm{~mm}$, and thorax width $1.809 \mathrm{~mm}$ to $2.329 \mathrm{~mm}$. For future research, it is suggested that this study can look into the genetic status of this species.
\end{abstract}

Keywords: Characteristic, morphology, Heterotrigona itama, pollinator, stingless bee.

\section{Introduction}

Bees are the most important and effective pollinator compared to other groups of insects (Siregar et al., 2016). There are many species of bee in the world. One of them is Meliponines or stingless bees. Meliponines are the biggest group of eusocial bees and more than 600 species have been identified (Lavinas et al., 2019). Meliponines or stingless bees, one of the species, are similar to honey bees but different in morphology and size. Both groups play an important role in helping plants distribute their pollen grains for fertilization and for the survival of the plant species. Stingless bees are much smaller than the honey bees.

The size of the stingless bees and their body surface texture make it easier for the pollen grains to stick on the body. They also a have unique behavior as they produce sound and perform a dance to inform the colony the location of the food (Nieh, 1998). Heterotrigona itama is the species belonging to genus Heterotrigona. It is one of the most common domesticated stingless bee species in Malaysia (Azmi et al., 2019). Table 1 shows the taxonomic hierarchy of $H$. itama. The external morphology of a stingless bee can be divided into three main parts: head, thorax and abdomen (Kwapong et al., 2010). A stingless bee is smaller than a honey bee and all species look almost the same. Therefore, one way to differentiate all species of stingless bees is by using their morphology characteristic. External parts such as wing, colour and size are important to classify the species (Aytekin et al., 2007). Figure 1 shows the morphology of $H$. itama. 


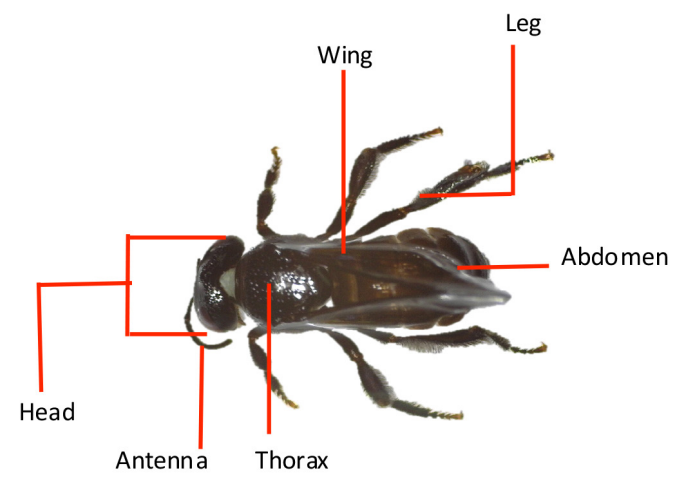

Figure 1: The morphology of Heterotrigona itama adult

Stingless bees live in one huge colony. One colony composes a thousand workers and single queen that controls them (Jailani et al., 2019). Males have no specific work in the hive or nest but outside, they fertilize the virgin queen the repace the mother queen (Sommeijer et al., 2003). Stingless bees utilise the resin from many different plants for food, defenses and build the nest (Sakagami, 1982; Wilms et al., 1996; Leonhardt et al., 2009). In one colony there is a queen, male stingless bees and workers. The size of the queen is usually bigger than the male and worker bees and the queen loses the ability to fly (Michener, 1974; Efin et al., 2019). Usually, the worker bees are female and they will go out looking for food or nectar while the male bees will be the queen mating partner (Miller et al., 2009). The majority of the bees in the colony are the female bees and few of them are males.

Morphology studies can be an added tool for the identification of the species along with molecular studies. According to Smith (2012), some morphology characters will directly indicate the species of stingless bees such as rear of propodeum with hairless, shiny bare spot and hind tibia with plumose hair on posterior rim.
Measurement of the morphology will be helpful rather than just observing the characteristics of the stingless bees. Stingless bees that had been studied in this project was Heterotrigona itama. A few studies have been conducted on the morphology of stingless bees in Terengganu especially for $H$. itama. Therefore, the morphological characteristic of $H$. itama have been determined in this study to gain more data for morphological characteristic of this species.

\section{Materials and Methods}

\section{Sampling Site}

Sampling for $H$. itama was conducted in two areas in Terengganu which are in TKPM (Taman Kekal Pengeluaran Makanan) Kampung Peradong, Manir (Population A) and Big Bee Honey, Merchang (Population B) as shown in Figure 2. TKPM is the place for melon cultivation. 20 individuals of $H$. itama were collected from each sampling site. The samples were collected using an insect net from the hive and preserved in $10 \mathrm{~mL}$ of $95 \%$ ethanol in the universal bottle. Only worker bees were collected from both areas. 


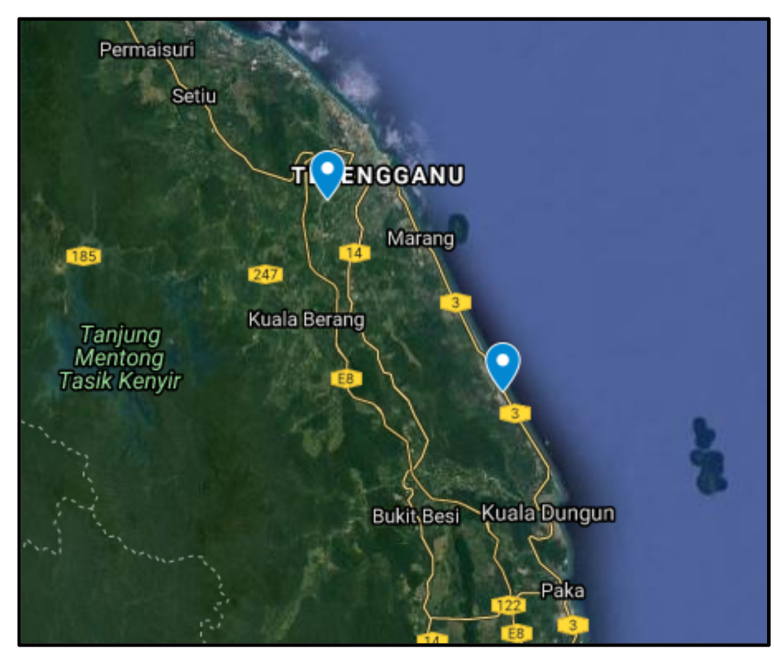

Figure 2: The location of apiary at Manir and Merchang, Terengganu (Note: Blue dots)

\section{Morphological Experiment}

Twenty individuals of $H$. itama were taken randomly from each group for morphological study. The head length, head width, body length, abdomen length, abdomen width, thorax length, thorax width, leg length, leg width, forewing length, forewing width and hindwing length and hindwing width of the specimen were measured by using DinoCapture 2.0 (Azmi et al., 2019).

\section{Data Analysis}

All data were analysed using Mann-Whitney U-test for statistical analysis in PAST (Paleontological Statistics) Software (Corder \& Foreman, 2011).

\section{Results and Discussion}

\section{Morphological Characteristics of} Heterotrigona itama

Two different types of morphological characteristics were determined between the two populations; (i) the external morphological measurement of $H$. itama such as length and width of body, abdomen, thorax, leg, wing and antenna and (ii) the body colour of H. itama. The body colour (black) of $H$. itama from both populations A and B showed no difference.

\section{Morphological Measurement of Heterotrigona itama}

The external morphology of $H$. itama between the two populations was measured and recorded. Table 1 shows the measurement of the external morphology of $H$. itama. The measurements include body length, head length and width, abdomen length and width, thorax length and width, foreleg, mid-leg, hind leg, tibia width, forewing length and width, hindwing length and width and antenna length. 
Table 1: Morphological measurement of $H$. itama from population $A$ and $B(\mathrm{~N}=40)$

\begin{tabular}{|c|c|c|c|c|c|}
\hline \multirow{2}{*}{$\begin{array}{c}\text { Morphological } \\
\text { Characteristics } \\
\text { (mm) }\end{array}$} & \multicolumn{2}{|c|}{ Population A } & \multicolumn{2}{|c|}{ Population B } & \multirow{2}{*}{$\begin{array}{c}\text { Mann-Whitney } \\
\text { U-test } \\
\text { (p-value) }\end{array}$} \\
\hline & Range & Mean \pm SD & Range & Mean \pm SD & \\
\hline Body length & $4.860-7.823$ & $6.141 \pm 0.575$ & $5.099-7.026$ & $6.415 \pm 0.782$ & 0.203 \\
\hline Head length* & $1.230-2.495$ & $1.847 \pm 0.233$ & $1.179-2.152$ & $2.058 \pm 0.293$ & 0.002 \\
\hline Head width* & $1.685-2.773$ & $2.254 \pm 0.196$ & $1.743-2.557$ & $2.426 \pm 0.249$ & 0.002 \\
\hline Abdomen length & $2.007-3.915$ & $2.799 \pm 0.417$ & $1.984-3.434$ & $2.995 \pm 0.507$ & 0.443 \\
\hline Abdomen width & $1.361-2.514$ & $1.988 \pm 0.408$ & $1.030-2.972$ & $1.926 \pm 0.346$ & 0.757 \\
\hline Thorax length & $1.487-2.574$ & $2.133 \pm 0.303$ & $1.633-2.805$ & $2.192 \pm 0.305$ & 0.316 \\
\hline Thorax width* & $1.449-2.678$ & $2.093 \pm 0.126$ & $1.809-2.329$ & $2.251 \pm 0.323$ & 0.045 \\
\hline Foreleg & $2.039-4.710$ & $3.113 \pm 0.489$ & $2.095-3.775$ & $3.264 \pm 0.705$ & 0.432 \\
\hline Mid-leg & $3.080-5.261$ & $4.431 \pm 0.497$ & $3.711-5.516$ & $4.433 \pm 0.594$ & 0.604 \\
\hline Hind leg & $4.491-6.737$ & $5.592 \pm 0.459$ & $4.540-6.483$ & $5.589 \pm 0.632$ & 0.906 \\
\hline Tibia width & $0.569-0.986$ & $0.750 \pm 0.131$ & $0.532-0.997$ & $0.796 \pm 0.111$ & 0.280 \\
\hline Forewing length & $3.557-6.640$ & $5.390 \pm 0.276$ & $4.865-5.930$ & $5.269 \pm 0.947$ & 0.780 \\
\hline Forewing width & $1.362-2.494$ & $2.487 \pm 0.757$ & $1.867-3.964$ & $1.930 \pm 0.425$ & 0.150 \\
\hline $\begin{array}{l}\text { Hindwing } \\
\text { length }\end{array}$ & $2.475-4.232$ & $3.307 \pm 0.749$ & $1.928-3.964$ & $3.475 \pm 0.620$ & 0.480 \\
\hline Hindwing width & $0.707-1.491$ & $0.989 \pm 0.110$ & $0.692-1.098$ & $0.958 \pm 0.227$ & 0.881 \\
\hline Antenna length & $1.386-3.380$ & $2.428 \pm 0.321$ & $1.560-2.985$ & $2.502 \pm 0.610$ & 0.370 \\
\hline
\end{tabular}

Notes: * shows significant difference between populations A and B (Mann-Whitney, p $<0.05$ )

Based on Table 1, three characteristics of $H$. itama of population B such as head length, head width and thorax width could be considered larger in size than population $\mathrm{A}$, with the range of head length at $1.179 \mathrm{~mm}$ to $2.152 \mathrm{~mm}$, head width $1.743 \mathrm{~mm}$ to $2.577 \mathrm{~mm}$, and thorax width $1.809 \mathrm{~mm}$ to $2.329 \mathrm{~mm}$. Mann-Whitney test shows there were significant differences in measurement for head length $(p=0002 ; p$ $<0.05)$, head width $(\mathrm{p}=0.002 ; \mathrm{p}<0.05)$ and thorax width $(\mathrm{p}=0.045 ; \mathrm{p}<0.05)$. However, there were certain morphological measurements of population A such as hind leg, forewing length, forewing width and hindwing width and antenna length which were greater than population B but not significantly different. Studies have been done regarding the morphological measurement of H. itama at Tasik Kenyir and the average measurement for the length of the legs was 4.25 $\pm 0.05 \mathrm{~mm}$ and width of the wing was $4.24 \pm$ $1.03 \mathrm{~mm}$ (Azmi et al., 2019). The variation in the body length of the Hitama worker can be related to the larval food obtained by the worker bee during the larval stage. Based on Quezada-Euán et al. (2011), there was a positive correlation between body size with the amount of protein content of larval food. Besides protein, nitrogen could also be a good source of larvae food (Eltz 
et al., 2002). Pollen seems to be a good source of nitrogen as well. Based on the area of both stingless bee, population A stingless bees were located at TKPM (Taman Kekal Pengeluaran Makanan) Peradong, Manir, where many crops such as melons are planted hence it will be easy for the stingless bees to find the food source. For population B, the area is located at Kampung Jambu Bongkok, Merchang. The place is surrounded by trees, but not as many as in the location where population $\mathrm{A}$ is found.

\section{Conclusion}

In conclusion, the morphological characteristics of H. itama from two different study sites have been determined. There were differences in the morphological characters of H. itama such as head length, head width and thorax width showed significant differences for both sites for population A and population $\mathrm{B}$. This is due to the fact both the sites share different characteristics. This result will be useful to establish a baseline of data about stingless bees in Malaysia and also for the management and conservation of stingless bees and their ecosystem as well. For future studies, it is suggested more individuals from various localities could be included to increase the reliability of the data about morphological characteristics of $H$. itama in Terengganu and it is also suggested that this study can be continued for the genetic structure of this species.

\section{Acknowledgements}

We would like to thank the Faculty of Science and Marine Environment and Central Laboratory of Universiti Malaysia Terengganu for providing the necessary equipment and facilities for the completion of this project. We are also grateful to the owner of TKPM and Big Bee Honey for the sampling process.

\section{References}

Aytekin M. A., Terzo., Rasmont, P., \& Cagatay, N. (2007). Landmark based geometric morphometric analysis of wing shape in Sibiricobombus Vogt (Hymenoptera: Apide: Bombus Latreille). In Annales de la societe Entomologique de France, 43(1), 95-102.

Azmi, W. A., Ghazi, R., \& Nasharuddin, I. S. (2019). Morphological, nest architecture and colony characteristics of stingless bees (Hymenoptera; Apidae; Meliponini) from Tasik Kenyir, Terengganu. In Greater Kenyir Landscapes: Social Development and Environmental Sustainability: From Ridge to Reef (pp. 111-121). Springer International Publishing.

Corder, G., \& Foreman, D. (2011). Nonparametric Statistics for NonStatisticians. 1st ed. Hoboken: John Wiley \& Sons, 57-78.

Efin, A., Atmowidi, T., \& Prawasti, T. S. (2019). Short communication: Morphological characteristics and morphometric of stingless bee (apidae: Hymenoptera) from Banten Province, Indonesia. Biodiversitas, 20(6), 1693-1698.

Eltz, T., Brühl, C. A., \& Görke, C. (2002). Collection of mold (Rhizopus sp.) spores in lieu of pollen by the stingless bee Trigona collina. Insectes sociaux, 49(1), 28-30.

Quezada-Euán, J. J. G., López-Velasco, A., Pérez-Balam, J., Moo-Valle, H., VelazquezMadrazo, A., \& Paxton, R. J. (2011). Body size differs in workers produced across time and is associated with variation in the quantity and composition of larval food in Nannotrigona perilampoides (Hymenoptera, Meliponini) Insectes sociaux, 58(1), 31-38. 
Jailani, N. M. A., Mustafa, S., Mustafa, M. Z., \& Mariatulqabtiah, A. R. (2019). Nest Characteristics of Stingless Bee Heterotrigona itama (Hymenoptera: Apidae) upon colony transfer and splitting. Pertanika Journal of Tropical Agricultural Science, 42(2), 861-869.

Kwapong, P., Aidoo, K., Combey, R., \& Karikari, A. (2010). Stingless bees: Importance, management, and utilisation. A training manual for stingless beekeeping. Ghana: Unimax Macmillan Ltd.

Lavinas, F. C., Macedo, E. H. B., Sá, G. B., Amaral,A.C.F., Silva, J. R.,Azevedo, M. M., \& Rodrigues, I. A. (2019). Brazilian stingless bee propolis and geopropolis: promising sources of biologically active compounds. Revista Brasileira De Farmacognosia, 29(3), 389-399.

Leonhardt, S. D., N. Bluthgen., \& T. Schmitt. (2009). Smelling like resin: Terpenoids account for species-specific cuticular profiles in Southeast-Asian stingless bees. Insects Sociaux, 56: 157-170.

Michener, C.D., 1974. The social Behaviour of the Bee: A Comparative study. Belknap Press, Cambridge, MA.

Miller, D. M., Jamison, K., \& Wallace, R. (2009). The Buzz about Bees : Honey Bee Biology and Behavior. 4-H Honey Bee Leaders Guide Book I, (380-071), 1-12.
Nieh, J. C. (1998). The food recruitment dance of the stingless bee, Melipona panamica. Behavioral Ecology and Sociobiology, 43(2), 133-145. https://doi. org/10.1007/s002650050475

Sakagami, S. F., (1982). Stingless bees. In: Hermann, H. R. (ed.), Social Insects, Volume 2. Academic Press, New York. Pp. 361-423.

Siregar, E. H., Atmowidi, T., \& Kahono, S. (2016). Diversity and Abundance of Insect Pollinators in Different Agricultural Lands in Jambi, Sumatera. HAYATI Journal of Biosciences, 23(1), 13-17.

Smith, D.R. (2012).Key to Workers of IndoMalayan Stingless Bees. Department of Ecology and Evolutionary / Entomology: University of Kansas, USA.

Sommeijer, M.J., de Bruijn, L.L., Meeuwsen, F.J.A.J. \& Slaa, E.J. (2003). Reproductive behaviour of stingless bees: nest departures of non-accepted gynes and nuptial flights in Melipona favosa (Hymenoptera: Apidae, Meliponini). Entomologische Berichten-Nederlandsche Entomologische Vereenigung, 63(1): 7-13.

Wilms, W., V. L. Imperatriz-Fonseca \& W. Engels, (1996). Resource partitioning between highly eusocial bees and possible impact of the introduced Africanized honey bee on native stingless bees in the Brazilian Atlantic rainforest. Studies on Neotropical Fauna and Environment, 31: 137-151. 